\title{
Some psycho-social factors fostering workplace commitment among head teachers in Nigeria
}

Ogungbamila, Bolanle $\measuredangle$

Adekunle Ajasin University, Nigeria (o_bolanle@yahoo.com)

Fayankinnu, Emmanuel A.

Adekunle Ajasin University, Nigeria (emmanfay@gmail.com)

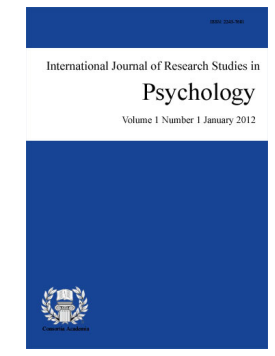

ISSN: 2243-7681 Online ISSN: 2243-769X

\section{Abstract}

This study investigated the extent to which head teachers' workplace commitment was associated with job satisfaction, social wellbeing, and socio-demographic variables. Respondents were 207 head teachers (116 males; 91 females) of selected primary schools in northwestern, Nigeria. Their ages averaged 49.13years ( $\mathrm{SD}=5.89)$. Results of the hierarchical multiple regression revealed that age, gender, marital status, and job tenure were not important in predicting head teachers' level of workplace commitment. Educational qualification was associated with a significant reduction in the level of workplace commitment. However, job satisfaction was associated with a significant increase in head teachers' commitment to the workplace. Similarly, life satisfaction significantly predicted workplace commitment such that head teachers who were satisfied with life tended to be highly committed to the workplace. The research, theory, and practical implications of the study were discussed.

Keywords: organizational commitment; satisfaction; well-being; teacher; Nigeria 


\section{Some psycho-social factors fostering workplace commitment among head teachers in Nigeria}

\section{Introduction}

There is continued effort by organizational experts, across the globe, to understand issues relating to workplace commitment. A plausible explanation for the continued interest in workplace commitment may be linked to its association with significant work outcomes such as absenteeism (Farell \& Peterson, 1984), presenteeism (Durna \& Eren, 2005), turnover intentions (Mathieu \& Zajac, 1990), job satisfaction (Buchanan, 1974), life satisfaction (Fayankinnu, 2010), and job performance (Meyer \& Allen, 1990; 1997).

In spite of the multiple definitions of workplace commitment in the literature (Blood, Ridenour, Thomas, Qualls \& Hammer, 2002; Lok, Westwood \& Crawford, 2005; Mathieu \& Zajac, 1990; Meyer \& Allen, 1997; Mowday Porter \& Steers, 1982; Ogungbamila, 2006), scholars agreed that commitment is an expression of a psychological state reflective of how employees feel about their engagement with the employing organization (Newstrom, 2007). In this regard, commitment entails employees' attitude towards imbibing the beliefs, values, norms, and goals of the organization, a demonstration of loyalty to the organization, willingness to exert efforts on behalf of the organization, and a desire to remain with the organization (Meyer \& Allen, 1997). In line with the foregoing, Lok et al. (2005) conceives of workplace commitment as employees' level of "identification and involvement with and loyalty to the (employing) organization" (p. 493).

As a result of the outcomes associated with workplace commitment, some researchers have focused on factors (e.g. age, tenure, gender, educational qualification, marital status, job satisfaction, and life satisfaction) with a view to improving the outcomes (Adenguga, Adenuga, \& Ayodele, 2013; Salami, 2008; Ogungbamila, 2006; Chughtai \& Zafar, 2006). Findings, however, have been mixed. While some studies found a significant correlation between the antecedent variables (such as age, tenure, gender, educational qualification, marital status, job satisfaction, and life satisfaction) and workplace commitment (Brown, 2003; Iqbal, 2010; Meyer, Stanley, Herscovitch \& Topolnytsky, 2002; Newstrom, 2007; Salami \& Omole, 2005), others reported no significant correlation with workplace commitment (Al-Ajimi, 2006; Cole, 2004; van der Velde, Bossink, \& Jansen, 2003). Yet, other studies (e.g. Eskildsen, Kristensen, \& Westlund, 2004; Wiedmer 2006; Mathieu \& Zajac, 1990) showed an inverse relationship between psycho-social factors and workplace commitment.

In Nigeria, workplace commitment has received moderate attention from scholars. This is evidenced by studies investigating the association between workplace commitment and factors such as age, tenure, gender, educational qualification, marital status, job satisfaction, and life satisfaction among employees in banks, local government secretariats, tertiary institutions, hospitals, and regimented organizations (Adenguga et al., 2013; Alarape \& Akinlabi, 2000; Ogungbamila, 2006). In spite of the focus on workplace commitment, none of the reviewed studies examined the relationship between workplace commitment and the listed psycho-social factors among head teachers in Nigerian primary schools. A possible reason for the neglect of scholars' attention on head teachers' commitment to the workplace may be consequent to the relative decline in the significance attached to the roles now played by the head teachers.

Although previous studies overseas (e.g. Blood et al., 2002; Mwamwenda, 1995) have investigated head teachers' commitment, findings from such studies do not provide adequate explanation for the situation in Nigeria, particularly given the considerable variations in the socio-cultural settings of the two groups of society. This gap renders it difficult to understand the dynamics of psycho-social factors that foster head teachers' commitment in Nigeria. Thus, there is the need to investigate psycho-social factors that predict head teachers' commitment, given that they are saddled with the responsibility of planning, for organizing, coordinating and motivating teachers and pupils under their control with a view to improving performance. This study was 
targeted at filling the lacuna.

\subsection{Personal factors in workplace commitment}

Al-Ajimi (2006) and van der Velde et al. (2003) found no significant relationship between age and commitment. Prior to this, Meyer and Allen (1984) had reported an inverse relationship between age and workplace commitment. According to them, younger employees' commitment towards their organization may increase if they realize that, with insufficient work experience, job opportunities are limited. However, some studies (e.g. Chughtai \& Zafar, 2006; Cohen \& Lowenberg, 1990; Ingersoll, Olsan, Drew-Cates, De Vinney, \& Davies, 2002) reported a positive relationship between age and workplace commitment. Some explanations for the positive relationship are that as individual employees grow older, commitment towards employing organization increases given that they are left with limited alternative job opportunities. Additionally, older employees tend to have a stronger investment and greater history with their organization compared to younger employees (Sekaran, 2000; Mathieu \& Zajac, 1990). Drawing from Sekaran (2000) and Mathieu and Zajac (1990), we hypothesized that:

Hypothesis 1a: Workplace commitment increases with age.

Apart from age, gender can also be an important factor in workplace commitment among head teachers. This is because studies reported significant correlation between gender and workplace commitment (Du, Song, Liu, \& Picken, 2007; Khan, Ziauddin, Jam, \& Ramay, 2010; Lim, 2003; Lok \& Crawford 2004). Mathieu and Zajac (1990) reported that women are more committed to the workplace than men. This may be because there are few job opportunities available for women (Aven, Parker, \& McEvoy, 1993). Other researchers (e.g. Cohen \& Lowenberg, 1990) found men to be more committed to the workplace than their female counterpart. Given the Nigerian socio-cultural environment, which tends to ascribe more responsibilities to men as the bread winners of their family than women, it is expected that men would show higher level of commitment to the workplace that provides them with the opportunities to fulfill their socio-cultural roles. It was, therefore, hypothesized as follows:

Hypothesis $\mathbf{1 b}$ : Gender predicts workplace commitment; with men showing higher level of commitment than women.

In line with the socio-cultural hypothesis, marital status may come with additional socio-economic responsibilities which may affect employees' commitment to the workplace. Some studies found that married employees are less committed than unmarried employees given that the former have to cope with dual roles of home and workplace (Wiedmer, 2006). Other studies reported a contrary result. For example, Ajiboye (2008), Dodd-McCue and Wright (1996), and Morrow (1993) found that married employees are more committed than unmarried employees. This may be because married employees, especially in Nigeria, saw their jobs as a major means of sustaining their families; thus, increasing their levels of workplace commitment would further guarantee the survival of the family. Therefore, it was hypothesized that:

Hypothesis 1c: Marital status predicts workplace commitment such that married employees are more committed to the workplace than unmarried employees.

Another important personal factor in workplace commitment is job tenure. Studies on the relationship between job tenure and workplace commitment produced mixed results. For example, McFarlin and Sweeney (1992) and Roodt (1992) found no relationship between job tenure and workplace commitment. However, job tenure has been found to have a significant influence on workplace commitment (Ayinde, 2011; Meyer et al., 2002; Salami, 2008; Wright \& Bonett, 2002). This may be because employees who have spent long time on a job tended to develop a high sense of responsibility for organizational and job outcomes. Against this background, it was hypothesized that: 
Hypothesis 1d: Workplace commitment increases with job tenure.

The level of workplace commitment of head teachers could also be connected with academic qualification. This is because previous studies indicated that a strong relationship exists between employees' level of education and workplace commitment. For example, Mathieu and Zajac (1990) and Mowday et al. (1982) argued that the higher the employees' level of education, the lower their level of commitment to the workplace. This might be because employees with higher educational qualification have more opportunities for alternative employment and mobility. Based on this, it was hypothesized that:

Hypothesis 1e: Workplace commitment decreases with employees' level of educational qualification.

\subsection{Psychological factors in workplace commitment}

Job satisfaction, which refers to employees' positive feelings toward their job and employer (Bullock, 2003), could be a strong factor in workplace commitment among head teachers. As theorized by the norm of reciprocity of the social exchange theory, employees would exhibit positive job attitudes and behavior (including workplace commitment) towards an organization that provides a satisfying job, employee-friendly work environment and reward system (Cropanzano \& Mitchell, 2005; Folger \& Cropanzano, 2001).

Spector (1997) reported strong links between job satisfaction and important organizational outcomes. This may be because of the association of job satisfaction with employees' retention and commitment to work (Griffith, 2004). In the last two decades, studies (e.g. Lee, Carswell \& Allen, 2000; Meyer et al., 2002; Yin \& Yang, 2002) have reported a strong positive link between teachers' job satisfaction and workplace commitment. By extension, we expect that head teachers who are satisfied with their jobs would extend the positive feelings to the workplace. Consequently, it was hypothesized that:

Hypothesis 2: Job satisfaction predicts workplace commitment such that head teachers who are highly satisfied with their job tend to be more committed to the workplace than those with low job satisfaction.

If a job enhances employees' satisfaction (with life), it is likely that such employees would be more satisfied with the job and be more committed to the workplace that provided the favorable job atmosphere. Therefore, employees' level of life satisfaction may be related with workplace commitment. There seems to be no consensus among researchers on the concept of life satisfaction. Consequently, Ryan and Deci (2001) categorized the definitions of life satisfaction into two perspectives: hedonism and eudemonism.

Hedonism conceives life satisfaction to encompass pleasure or happiness and the absence of pain in all aspects of life (Diener, Sapyta, \& Suh, 1998; Kahneman, Diener, \& Schwarz, 1999). In contrast, eudemonism sees life satisfaction beyond mere happiness or pleasure. Rather, life satisfaction is the actualization of one's potentials or the achievement of one's goal in life (Ryan \& Deci, 2001). From this view, life satisfaction is a condition that connotes that one's life activities are in consonant with one's beliefs or values. Thus, employees' levels of life satisfaction can be measured through their experiences of the indicators of well-being such as self-acceptance, autonomy, and personal growth (Ryff \& Keyes, 1995) as well as feelings of self-actualization, meaning, and vitality (Ryan \& Deci, 2001)

The few studies that investigated the link between life satisfaction and workplace commitment reported a positive correlation between employees' satisfaction with life and workplace commitment (Huff, 2001; Redman \& Snape, 2006). This suggests that employees who report a high level of life satisfaction tend to be more committed to the workplace. Therefore, the following hypothesis was formulated:

Hypothesis 3: Life satisfaction predicts workplace commitment such that head teachers who reported high satisfaction with life are highly committed to the workplace. 


\section{Methods}

\subsection{Participants and procedure}

This cross-sectional survey involved 207 head teachers (116 males; 91 female) randomly selected from 16 Local Government Areas (LGAs) of a State in northwestern Nigeria. Head teachers were the focus of this study because the sub-ordinates' level of commitment to the workplace might be associated with the extent to which the headship of organization feels emotionally attached to the organization. The 16 LGAs were randomly selected using the Table of Random Numbers. The list of private and public primary schools, arranged in alphabetical order, was obtained from the Local Education Authority in each LGA. Based on the list, the head teachers of the 220 schools (110 private; 110 public) that fell on odd numbers were selected. The participants were provided with moderate information about the research that would enable them to decide whether or not to participate in the study. Therefore, participation in the study was voluntary. Participants were assured of the confidentiality of their responses and that they were free to discontinue with the study whenever they felt. Out of the 220 head teachers sampled, 210 were willing to participate in the study. Out of the 210 questionnaires distributed, 207 were duly completed, found usable, and analyzed.

The respondents' ages ranged between 43 and 55 years $\left(M_{\text {age }}=49.13\right.$; SD $\left.=5.89\right)$. They had spent an average of 26.2 years on the job $(\mathrm{SD}=7.46)$. In respect of post tenure, the respondents indicated that they had spent an average of 3.6 years $(\mathrm{SD}=1.95)$ as head teachers. Majority of them $(204$ or $98.6 \%)$ were married, 3 $(1.4 \%)$ were single. The respondents also indicated their highest academic qualification: 55(26.6\%) had National Certificate in Education, 93 (44.9\%) had first degree, and 59 (28.5\%) had postgraduate degree. The respondents were also asked to indicate whether or not they had other sources of income: $136(65.7 \%)$ said "yes" and $71(34.3 \%)$ said "no".

\subsection{Measures}

Workplace commitment was measured using Buchanan's (1974) Organizational Commitment (OC) scale. It was a 23-item scale designed to measure the extent to which employees are affectively attached to the achievement of the goals and values of the organization. OC assesses 3 components of workplace commitment (identification $=6$ items; job involvement $=6$ items; and loyalty $=13$ items). OC was predicated on a 7-point scale ( 1 = strongly disagree; 7 = strongly agree). Sample items included: "I feel a sense of pride in working in this organization" (identification); "I live, eat and breathe my job" (job involvement); and "I feel a strong sense of loyalty toward this organization" (loyalty). Buchanan (1974) reported a coefficient alpha of .94 for the overall scale. In this study, we found a Cronbach's alpha of .87 for the overall scale. High score on the measure of workplace commitment was an indication that the head teachers were highly attached to the goals and values of the workplace.

Job satisfaction was assessed using Minnesota Satisfaction Questionnaire (MSQ) - Weiss, Dawis, England and Lofquist (1967). This 20-item inventory was designed to measure the extent to which employees derive fulfillment from their job environment. MSQ was measured on a 5-point scale $(1=$ very dissatisfied; $5=$ very satisfied). Sample item included: "The working conditions". Weiss et al. (1967) reported a one-week test re-test reliability coefficient of .89 for the scale. In the present study, we obtained a Cronbach's alpha of .87. High score on MSQ was an indication that the head teachers felt a high sense of fulfillment with their job environment.

Life satisfaction was measured with Satisfaction with Life Scale (SWLS) developed by Diener, Robert, Emmons, Larsen, and Griffin (1985). SWLS was designed to measure the extent to which individuals feel comfortable with life. It was a 5-item inventory predicated on a 7-point scale $(1=$ strongly disagree; $7=$ strongly agree). Sample items included: "If I could live my life over, I would change almost nothing”. Diener et al. (1985) reported a two-month test re-test reliability coefficient of .82 for the scale. We obtained a Cronbach's alpha of .77 with the present sample. High score on SWLS showed that the head teachers felt highly satisfied with life 
Ogungbamila, B. \& Fayankinnu, Emmanuel A.

whereas low score indicated low life satisfaction.

\section{Results}

\subsection{Test of Relationships among the Variables}

Table 1 shows the results of the descriptive and inter-variable correlations.

\section{Table 1}

Mean, SD, and Inter-variable Correlations

\begin{tabular}{|c|c|c|c|c|c|c|c|c|c|c|c|c|}
\hline Variables & $M$ & $S D$ & 1 & 2 & 3 & 4 & 5 & 6 & 7 & 8 & 9 & 10 \\
\hline 1. Age & 41.13 & 5.89 & 1 & & & & & & & & & \\
\hline 2. Gender & - & - & $.24 * *$ & 1 & & & & & & & & \\
\hline 3. Marital status & - & - & .02 & .03 & 1 & & & & & & & \\
\hline 4. Academic qualification & - & - & .12 & .06 & .01 & 1 & & & & & & \\
\hline 5. Post tenure & 3.56 & 1.95 & .05 & -.11 & -.05 & -.12 & 1 & & & & & \\
\hline 6. Job tenure & 26.18 & 7.46 & $.54 * *$ & $.26 * *$ & -.03 & -.04 & .04 & 1 & & & & \\
\hline 7. Additional source of income & - & - & .06 & .03 & -.00 & .01 & -.04 & .06 & 1 & & & \\
\hline 8. Job satisfaction & 92.59 & 22.36 & .00 & .02 & .00 & -.10 & -.09 & .07 & -.07 & 1 & & \\
\hline 9. Life satisfaction & 22.17 & 8.06 & .04 & .02 & -.03 & -.05 & .01 & -.02 & -.05 & $.39 * *$ & & \\
\hline 10.Workplace commitment & 73.48 & 20.29 & .02 & -.03 & -.07 & $-.16^{*}$ & -.09 & -.05 & -.02 & $.61 * *$ & $.50 * *$ & 1 \\
\hline
\end{tabular}

Note. ${ }^{*} p<.01$. $* p<.05 . \mathrm{N}=207$. Gender was coded as male $=0$, female $=1$. Marital status was coded as single $=0$; married $=1$. Academic qualification was coded as National Certificate in Education $=1$; first degree $=2$; postgraduate degree $=3$. Additional source of income was coded as $\mathrm{No}=0$, Yes $=1$

As shown in Table 1, except academic qualification, none of the socio-demographic variables had significant relationship with workplace commitment. Academic qualification was significantly related with head teachers' level of workplace commitment such that head teachers who had higher academic qualifications tended to be less committed to the workplace $[r(205)-.16, p<.05]$. The results in Table 1 also indicate that job satisfaction had a significant relationship with workplace commitment such that head teachers who felt satisfied with their job were also committed to the workplace $[r(205) .61, p<.01]$. Similarly, head teachers who reported high satisfaction with life tended to be highly committed to the workplace $[r(205) .50, p<.01]$.

\subsection{Test of Hypothesis}

We tested hypotheses 1a, 1b, 1c, 1d, 1e, 2, and 3 with a 2-step hierarchical regression. The socio-demographic variables were entered into the regression model in step 1 . In model 2, we entered the independent effects of the psychological variables (job satisfaction and life satisfaction). The results are presented in Table 2.

As indicated in Table 2 , head teachers' age $(\beta=.12, p>.05)$, gender $(\beta=-.03, p>.05)$, marital status $(\beta=$ $-.05, p>.05)$, and job tenure $(\beta=.13, p>.05)$ were not important in predicting workplace commitment. These imply that head teachers would be committed to the workplace irrespective of their age, gender, marital status, and job tenure. Therefore, hypotheses 1a, 1b, 1c, and 1d were not supported. Hypothesis 1e was however, supported. Academic qualification significantly predicted head teachers' level of workplace commitment such that commitment decreased as employees acquired higher academic qualifications $(\beta=-.21, p<.01)$. All the socio-demographic variables accounted for $11 \%$ changes in head teachers' level of workplace commitment $(R$ $\left.=.33, R^{2}=.11, p<.05\right)$.

The results in Table 2 provided evidence in support of hypotheses 2 and 3. As predicted in hypothesis 2 , job satisfaction significantly predicted head teachers' level of commitment to the workplace. Table 2 indicates that head teachers who felt highly satisfied with their jobs were also highly committed to the workplace $(\beta=.30, p$ 
Workplace commitment among head teachers

$<.001)$. Life satisfaction significantly predicted workplace commitment such that head teachers' commitment increased with their level of reported life satisfaction $(\beta=.46, p<.001)$. The inclusion of job satisfaction and life satisfaction in model 2 , accounted for $51 \%$ changes in head teachers' level of workplace commitment.

Table 2

Hierarchical Multiple Regression on Workplace Commitment

\begin{tabular}{llllll}
\hline Model & $\beta$ & $R$ & $\mathrm{R}^{2}$ & $\Delta R^{2}$ & $F$ \\
\hline Model 1 & & .12 & .11 & .11 & $2.15^{*}$ \\
Age & -.03 & & & \\
Gender & -.05 & & & \\
Marital status & $-.21^{* *}$ & & & \\
Academic qualification & -.09 & & & \\
Post tenure & -.13 & & & \\
Job tenure & -.03 & & & \\
Additional source of income & & & \\
Model 2 & .08 & & .51 & \\
Age & -.04 & & & \\
Gender & -.05 & & & \\
Marital status & -.13 & & \\
Academic qualification & -.05 & & \\
Post tenure & -.11 & & \\
Job tenure & .02 & & \\
Additional source of income & $.30^{* * *}$ & & \\
Job satisfaction & $.46^{* * *}$ & & \\
Life satisfaction & & & \\
Note & & & \\
\end{tabular}

Note. ${ }^{* * *} p<.01 . * * p<.01 . * p<.05 . \mathrm{N}=207$. Gender was coded as male $=0$, female $=1$. Marital status was coded as single $=0$; married $=1$. Religious affiliation was coded as Christianity $=0$, Islam $=1$. Academic qualification was coded as National Certificate in Education $=1$; first degree $=2$; postgraduate degree $=3$. Additional source of income was coded as No $=0$, Yes $=1$

\section{Discussion}

Studies on the extent to which workplace commitment was associated with psycho-social variables produced mixed results. Limited studies have focused the connection between workplace commitment and psycho-social variables such as age, gender, marital status, job tenure, academic qualification, job satisfaction, and life satisfaction, especially among head teachers in Nigeria. The importance of this study is underscored by the belief that head teachers could play a strategic role in enhancing the commitment of their sub-ordinates, which may have positive effects on students' academic and moral behaviors.

The current study found that age and job tenure did not exert strong influence on workplace commitment among head teachers (hypotheses 1a and 1d). These results corroborated the findings of Al-Ajimi (2006) and van der Velde et al. (2003) that workplace commitment was not related with age. Similarly, Roodt (1992) found that workplace commitment was not related with how long employees had worked for an organization. Going by the results of the current study, Serekan's (2000) and Mathieu and Zajac's (1990) submissions on the relationship between age and workplace commitment as well as Ayinde's (2011) results on job tenure and workplace commitment were not tenable. This may be because all the respondents were at the same job position (head teachers). At that position, age may not be a strong factor in workplace commitment because the position of head teacher in Nigeria is usually associated with an age bracket and a range of job experience.

Hypothesis $1 \mathrm{~b}$ was not supported by the results in Table 2. Women were as committed to the workplace as men. Our expectation that men would display higher level of workplace commitment than women, which was based on Cohen and Lowenberg's (1990) results, was not confirmed. The results of Du et al. (2007), Khan et al. (2010), and Lok and Crawford (2004) that women were more committed than men was equally negated by the 
findings of the current study. The workplace might have provided equal opportunities for men and women head teachers to meet their socio-economic responsibilities (e.g. attending to other family needs). This might have accounted for the lack of gender differences in workplace commitment among the head teachers.

Contrary to our expectation in hypothesis 1c, married employees were not in any way more committed to the workplace than unmarried employees. This negated the two opposing results on the association between marital status and workplace commitment. Wiedmer (2006) reported that unmarried employees tended to be more committed to the workplace than married employees. But Ajiboye (2008) found that married employees were more committed to the workplace than unmarried employees. The lack of connection between employees' marital status and their level of workplace commitment might be because, irrespective of marital status, employees had dependants which the job and the organization helped them to support. The high level of unemployment in Nigeria might have placed both married and unmarried employees at a similar level of social and economic obligations, which the job provided the opportunity to meet. It was, therefore, not out of place for married and unmarried head teachers to display similar level of commitment to the workplace that gave them the enablement to meet their socio-economic obligations.

The hypothesis on the relationship between academic qualification and workplace commitment (hypothesis 1e) was supported by the results in Table 2. Academic qualification accounted for $4.4 \%$ reduction in head teachers' level of workplace commitment. This confirmed the argument of Mathieu and Zajac (1990) and Mowday et al. (1982) that workplace commitment reduces as academic qualification increases. This implies that head teachers who had higher academic qualification (postgraduate degree) tended to be less committed to the workplace than those had lower qualification (National Certificate in Education). Those with higher academic qualification might have felt that they were over-qualified for the position. The lower level of workplace commitment displayed by this group of head teachers might be a way of reacting to the organization's unwillingness to recognize and adequately compensate them for the additional academic qualification. Apart from that, those with higher academic qualification have more job opportunities than those with lower academic qualification. Therefore, there was no need to be loyal to the organization.

The results of the current study on the relationship between job satisfaction and workplace commitment were in tandem with the findings of Meyer et al. (2002), Yin and Yang (2002), and Lee et al. (2000). They reported that teachers' level of workplace commitment increased with the extent to which they were satisfied with their job. Nigerian head teachers might have shown high level of commitment to the workplace because it provided the opportunity to enjoy their job. This confirmed the position of the norm of reciprocity and the social exchange theory that employees exhibit positive job attitudes and behavior towards the organization in return for the organization's display of employee-friendly work environment and reward system (Cropanzano \& Mitchell, 2005; Folger \& Cropanzano, 2001). The job rewards and favorable work environment might have engendered high job satisfaction, which the head teachers reciprocated with high commitment to the workplace for creating the atmosphere that promotes job satisfaction. That might explain why Job satisfaction was associated with $9 \%$ changes in head teachers' commitment to the workplace.

Life satisfaction, as hypothesized in hypothesis 3, was associated with $21.2 \%$ changes in head teachers' level of workplace commitment. The results of the current study confirmed the findings of previous studies (Huff, 2001; Redman \& Snape, 2006) that life satisfaction was strongly associated with increased workplace commitment. This may be because the organization provided them with a satisfying job that enhanced their satisfaction with life. Consequently, they were obliged to exhibit loyalty to the workplace in order to continue to enjoy the satisfying job.

\section{Conclusion}

The current study extended the literature on how workplace commitment was associated with employees' age, gender, marital status, job tenure, and academic qualification. Previous studies presented mixed results on 
the connections between workplace commitment and employees' personal characteristics. The current study showed that head teachers' personal characteristics, except academic qualification, were not connected with their level of workplace commitment. In tandem with previous studies, job satisfaction and life satisfaction were strongly associated with increased level of workplace commitment.

One of the unique contributions of the current study to literature was its sample. Workplace commitment among head teachers had been under-researched. Head teachers are important in enhancing the efficiency of the educational sector. This is because head teachers could play important roles in enhancing the commitment of teachers as well as student's academic performance. An understanding of the factors that foster head teachers' workplace commitment could be an important step in enhancing students' performance. Another contribution of this study was that it effectively situated the workplace commitment of head teachers in Nigeria within the norm of reciprocity of the social exchange theory (Cropanzano \& Mitchell, 2005; Folger \& Cropanzano, 2001). This has a practical implication for enhancing head teachers' level of workplace commitment. In order to enhance the level of workplace commitment of head teachers their jobs should not only be more satisfying but also lead to enhanced life satisfaction.

This study was not without some short-comings. A major short-coming of the study was that it was not clear whether the life satisfaction of the head teachers emanated from their job or other aspects of their life or a combination of many sources. This may cast some doubt on the linear connection between life satisfaction and workplace commitment. Apart from that, the results of the current study may not represent head teachers in Nigeria because the sample was drawn from one section of the country. Against this background, future studies should clarify the source(s) of life satisfaction (e.g. job-related life satisfaction) in relation to workplace commitment. A sample that reflects national spread may produce more beneficial results.

\section{References:}

Adenguga, R. A., Adenuga, F. T., \& Ayodele, K. O. (2013). Organizational commitment and turnover intention among private universities' employees in Ogun State, Nigeria. Open Journal of Education, 1(2), 31-36. http://dx.doi.org/10.12966/oje.05.04.2013

Ajiboye, S. O. (2008). Analysis of causal factors of work-family role conflict among male and female employees. Sociological Studies, 4(2), 93-104.

Al-Ajimi, R. (2006). The effect of gender on job satisfaction and organizational commitment in Kuwait. Management, 23(4), 838-844.

Alarape, A. I., \& Akinlabi, F. M. (2000). Influence of perceived organizational support and discretionary treatment on work attitude of industrial employees. African Journal for the Psychological Study of Social Issues, 5(1), 23-36.

Aven, F. F., Parker, B., \& McEvoy, G. M. (1993). Gender and attitudinal commitment to organizations: A meta-analysis. Business Research, 26, 63-73. http://dx.doi.org/10.1016/0148-2963(93)90043-O

Ayinde. A.T., (2011). Mediating role of psychosocial factors on the relationship between downsizing and employees' commitment to work among federal civil servants in Nigeria. Journal of Management and Strategy, 2(3), 2-12. http://dx.doi.org/10.5430/jms.v2n3p2

Blood, G., Ridenour, J., Thomas, E., Qualls, C., \& Hammer, C. (2002). Predicting job satisfaction among speech-language pathologists working in public schools. Language, Speech and Hearing Services in Schools, 33, 282-290. http://dx.doi.org/10.1044/0161-1461(2002/023)

Brown, B. B. (2003). Employees' organizational commitment and their perception of supervisors' relationsoriented and task-oriented leadership behaviour. Unpublished Doctoral Dissertation, Virginia Polytechnic Institute and State University. Falls Church, Virginia.

Buchanan, B. (1974). Building organizational commitment: The socialization of managers in work organization. Administrative Science Quarterly, 19, 533-546. http://dx.doi.org/10.2307/2391809

Bullock, L. M. (2003). The measurement of organizational commitment. Vocational Behaviour, 14, $224-247$. Chughtai, A., \& Zafar, S. (2006). Antecedents and consequences of organizational commitment among Pakistani 
University teachers. Applied Human Resource Management Research, 11, 39-64.

Cohen, A. (1993). Age and tenure in relation to organizational commitment: A meta-analysis. Basic and Applied Social Psychology, 14(2), 143-159. http://dx.doi.org/10.1207/s15324834basp1402_2

Cohen, A., \& Lowenberg, G. (1990). A re-examination of the side-bet theory as applied to organizational commitment: A meta-analysis. Human Relations, 43(10), 1015-1050. http://dx.doi.org/10.1177/001872679004301005

Cole, D. W. (2004). Social reflections on women playing dual roles: An assessment of women in leadership positions. Gender Studies, 7(2), 126-132.

Cropanzano, R., \& Mitchell, M. S. (2005). Social exchange theory: An interdisciplinary review. Journal of Management, 31, 874-900. http://dx.doi.org/10.1177/0149206305279602

Diener E., Emmons, R. A. Larsen, R. J., \& Griffin, S. (1985). The Satisfaction with Life Scale (SWLS). Journal of Personality Assessment, 49(1), 71-75. http://dx.doi.org/10.1207/s15327752jpa4901_13

Diener, E., Sapyta, J. J., \& Suh, E. (1998). Subjective well-being is essential to well-being. Psychological Inquiry, 9, 33-37. http://dx.doi.org/10.1207/s15327965pli0901_3

Dodd-McCue, D., \& Wright, G.B. (1996). Men, women and attitudinal commitment: The effects of workplace experiences and socialization. Human Relations, 49, 1065-1089. http://dx.doi.org/10.1177/001872679604900803

Du, J., Song, Y., Liu, C., \& Picken, D. (2007). Variance analyses of job satisfaction and organizational commitment versus demographic variables: A study on construction managers in Wuhan. Proceedings of the Sixth Wuhan International Conference on E-Business. New York: Alfred University Press.

Durna, U., \& Eren, V. (2005). The examination of organizational commitment in connection with three components of commitment. The Doğuş University Journal, 6(2), 210-219.

Eskildsen, J. K., Kristensen, K., \& Westlund, A. H. (2004). Work motivation and job satisfaction in the Nordic countries. Employee Relations, 269(2), 122-136. http://dx.doi.org/10.1108/01425450410511043

Farrell, D., \& Petersen, J. C. (1984). Commitment, absenteeism and turnover of new employees: A longitudinal study. Human Relations, 37, 681-692. http://dx.doi.org/10.1177/001872678403700807

Fayankinnu, E. A. (2010) Nigerian women prison workers' experiences of workplace violence. African Study Monograph, 31(1), 1-15.

Folger, R., \& Cropanzano, R. (2001). Fairness theory: Justice as accountability. In J. Greenberg \& R. Cropanzano (Eds.), Advances in organizational justice (pp. 1-55). Stanford, CA: Stanford University Press.

Griffith, J. (2004). Relation of principal transformational leadership to school staff job satisfaction, staff turnover, and school performance. Educational Administration, 42(3), 333-356. http://dx.doi.org/10.1108/09578230410534667

Huff, J. W. (2001). Application of attitude strength to job satisfaction: The moderating role of attitude strength in the prediction of organizational outcomes from job satisfaction. An Unpublished Doctoral Dissertation, Northern Illinois University, DeKalb.

Ingersoll, G. L., Olsan, T., Drew-Cates, J., De Vinney, B., \& Davies, J. (2002). Nurses' job satisfaction, organizational commitment, and career intent. Nursing Administration, 32(5), 250-263. http://dx.doi.org/10.1097/00005110-200205000-00005

Iqbal, A. (2010). An empirical assessment of demographic factors, organizational ranks and organizational commitment. Business and Management, 5(3), 21-38.

Kahneman, D., Diener, E., \& Schwarz, N. (Eds.) (1999). Well-being: The foundations of hedonic psychology. New York: Russell Sage Foundation.

Khan, R. M., Ziauddin, J, F. A., \& Ramay, M. I. (2010). The impacts of organizational commitment on employee job performance. European Journal of Social Sciences, 15(3), 292-298.

Lee, K., Carswell, J. J., \& Allen, N. J. (2000). A meta-analytic review of occupational commitment: Relations with persons- and work-related variables. Applied Psychology, 85(5), 799-811. http://dx.doi.org/10.1037/0021-9010.85.5.799

Lim, T. (2003). Relationship among organizational commitment, learning organizational culture, and job 
Workplace commitment among head teachers

satisfaction in one Korean private organization. Dissertation Abstracts International, 64(6), 2008A. UMI No.3092764.

Lok, P., \& Crawford, J. (2004). The effect of organizational culture and leadership style on job satisfaction and organizational commitment: A cross-national comparison. Management Development, 23(4), 321-338. http://dx.doi.org/10.1108/02621710410529785

Lok, P., Westwood, R., \& Crawford, J. (2005) Perceptions of organizational subculture and their significance for organizational commitment. Applied Psychology: An International Review, 54(4), 490-514. http://dx.doi.org/10.1111/j.1464-0597.2005.00222.x

Mathieu, J. E., \& Zajac, D. M. (1990). A review and meta-analysis of the antecedents, correlates, and consequences of organizational commitment. Psychological Bulletin, 108, 171-194. http://dx.doi.org/10.1037/0033-2909.108.2.171

McFarlin, D. B., \& Sweeney, P. D. (1992). Distributive and procedural justice as predictors of satisfaction with personal and organizational outcomes. Academy of Management, 35(3), 626-637. http://dx.doi.org/10.2307/256489

Meyer, J. P., \& Allen, J. N. (1984). Testing the Side-bet Theory of organizational commitment: Some methodological considerations. Applied Psychology, 69, 372-378. http://dx.doi.org/10.1037/0021-9010.69.3.372

Meyer, J. P., \& Allen, J. N. (1997). Commitment in the workplace. Thousand Oaks, CA: Sage Publications.

Meyer, J. P., Stanley, D. J., Herscovitch, L., \& Topolnytsky, L. (2002). Affective, continuance, and normative commitment to the organization: A meta-analysis of antecedents, correlates, and consequences. Vocational Behavior, 61, 20-52. http://dx.doi.org/10.1006/jvbe.2001.1842

Morrow, P. (1993). The theory and measurement of work commitment. CT: JAL, Greenwich.

Mowday, R. T., Porter L. W., \& Steers, R. M. (1982). Employee organization linkages: The psychology of commitment, absenteeism and turnover. New York: Academic Press.

Mwamwenda, T. S. (1995). Job satisfaction among secondary school teachers in Transkei. South African Journal of Education, 15(2), 84-86.

Newstrom, J. W. (2007). Organizational behaviour-human behaviour at work (12 ${ }^{\text {th }} \mathrm{ed}$.). New York: McGraw Hill International Edition.

Ogungbamila, B. (2006) Psychological needs and workplace commitment of selected local government employees. African Journal for the Psychological Study of Social Issues, 9(2), 152-161.

Redman, T., \& Snape, E. (2006). The consequences of perceived age discrimination amongst older police officers: Is social support a buffer? British Journal of Management, 17, 167-175. http://dx.doi.org/10.1111/j.1467-8551.2006.00492.x

Roodt, G. (1992). Organisasieklimaat as voorspeller van organisasieverbondenheid: Getuienis van 'n suiwer kognitiewe definisie? [Organization climate as predictor of organizational commitment: Evidence of a pure cognitive definition?] Acta Academica, 24(4), 109-122.

Ryan, R., \& Deci. E. (2001). Self-determination theory and the facilitation of intrinsic motivation, social development, and well-being. American Psychologist, 55, 68-78. http://dx.doi.org/10.1037/0003-066X.55.1.68

Ryff, C. D., \& Keyes, C. L. M. (1995). The structure of psychological well-being revisited. Personality and Social Psychology, 69, 719-727. http://dx.doi.org/10.1037/0022-3514.69.4.719

Salami, S. O. (2008), Demographic and psychological factors predicting organizational commitment among industrial employees. Anthropologist, 10, 31-38.

Salami, S. O., \& Omole, O. A. (2005). Participation in decision making process, incentives and training as predictors of organizational commitment among industrial employees. African Journal for the Psychological Study of Social Issues, 8(2), 210-227.

Sekaran, U. (2000). Research methods for business: A skill-building approach (2 ${ }^{\text {nd }}$ ed.). New York: John Wiley \& Sons, Inc.

Spector, P. E. (1997). Job satisfaction: Application, assessment, causes, and consequences. London: Sage Publications. 
Ogungbamila, B. \& Fayankinnu, Emmanuel A.

van der Velde, M. G., Bossink, C. J. H., \& Jansen, P. G. W. (2003). Gender differences in the influence of professional tenure on work attitudes. Retrieved from http://www.findartciles.com/p/artciles/mi_m2294

Weiss, D. J., Dawis, R. V., England, G. W., \& Lofquist, L. H. (1967). Manual for the Minnesota Satisfaction Questionnaire. Minnesota: IRC, University of Minnesota.

Wiedmer, S. M. (2006). An examination of factors affecting employee satisfaction. Retrieved from http://clearinghouse.missouriwestern.edu/manuscripts/51.asp

Wright, T. A., \& Bonett, D. G. (2002). The moderating effects of employee tenure on the relation between organizational commitment and job performance: A meta-analysis. Applied Psychology, 87(6), 1183-1190. http://dx.doi.org/10.1037/0021-9010.87.6.1183

Yin, J. T., \& Yang, K. A. (2002). Nursing turnover in Taiwan: A meta-analysis of related factors. International Journal of Nursing, 39(6), 573-581. http://dx.doi.org/10.1016/S0020-7489(01)00018-9 